\title{
Critical Discourse Analysis of Interpersonal Meaning and Power Relations in Selected Inaugural Political Speeches in Nigeria
}

\author{
Chinwe R. Ezeifeka* \\ http://dx.doi.org/10.4314/ujah.v14i2.3
}

\section{Abstract}

The paper discusses interpersonal meaning in two inaugural political speeches of Nigerian past leaders - President Olusegun Obasanjo's “The New Dawn” (1999) and Alhaji Shehu Shagari (1979). The focus is on aspects of the Mood structure of the clause that emphasize meaning as exchange of information, goods and services between interactants, namely, the Subject; and the speech functions of the clause as propositions or proposals and vocatives. A total of 178 and 161 clauses were selected from the two speeches respectively and analyzed using Halliday's systemic functional grammar (SFG) model and insights from critical discourse analysis (CDA). Our findings showed a deliberate oscillation between the use of singular Subject (I) and Plural Subject (We); rhetoric that in turns seems to take credit for positive achievement and divest responsibility for negative representations. The vocatives were also strategically positioned to assert solidarity, to ostensibly gain rapport and help to legitimize the power and hegemonic regime of the speakers. There was also high prevalence of propositions as against proposals giving the impression of more words and less action. The paper concludes that Nigerian politicians should be more committed to the proposals that offer goods and services to their subjects rather than making propositions that serve purely informative functions. 
Key words: interpersonal meaning, critical discourse analysis, political discourse, power relations, systemic functional linguistics, inaugural political speeches.

\section{Introduction}

The essence of language is to negotiate meaning and according to the functionalist tradition upon which most of the arguments in this paper derive their impetus, language conveys three meaning potentials simultaneously in social interaction. These include; ideational, interpersonal and textual meanings otherwise known as the "metafunctions" of language (Halliday and Matthiessen 61). This means that language transmits experience and reality (ideational), enacts social roles and relationships (interpersonal) and creates cohesive and coherent text (textual). In doing this, language draws on the resources of extralinguistic context (of situation) and lexicogrammar (textual features) (Halliday Explorations 36). This creation of meaning in a text as an interface between the social context and the lexicogrammar has been described by Halliday (Social Semiotic 40) as the "Social Semiotic".

Because people's lives are becoming increasingly shaped by textual representations which are politically, socially or economically motivated, coupled with the present explosion in information technology, there is need to create awareness on how these representations should be internalized - whose representations are they?, who gains what from them?, what social relations do they draw people into?, what are their ideological effects and what alternative representations are there? (Fairclough 75) According to McGregor (quoting Wodak online); "Our words are never neutral. They convey how we see ourselves as a profession, our identity, knowledge, values and beliefs and our truths. Our discourse permeates everything we do". 
Taking these insights to the Nigerian experience which is our point of focus in this work, we present two inaugural political speeches of our past leaders and pose these questions: What interpersonal roles did the political actors assign themselves in relation to their addressees in the speeches under review? How did the choices in the Mood system position the speakers as responsible agents in the exchange of information/goods and services to their subjects? What ideological positions were projected by the speeches?

\section{Political Speeches in the Nigerian Context}

Political speeches in Nigeria have been viewed with caution and skepticism because of the long history of failed promises and aborted dreams which these speeches represent. In addition, most Nigerian leaders have not lived up to the expectations in addressing the problems of the people, rather what obtained was a succession of self service, corruption, embezzlement and abuse of office to the extent that most Nigerians have lost interest in political speeches, which tend to be manipulative, deceitful, full of propaganda, thus masking the true situation.

The two speeches which form our textual data are important in the Nigerian political history as they represented hope, succour, and a source of freedom from dictatorship, corruption, human right abuses as well as provide employment for youth and improve living conditions. In fact according to Osuntokun, Aworawo and Masajuwa (228), Obasanjo's speech was regarded by the international community as "the second most important day in Africa's recent history, after Nelson Mandela's installation as president of South Africa". These inaugural speeches are hereby subjected to critical analysis to find out how the interpersonal meaning conveyed in the speeches represented the yearnings of the people, how the lexicogrammatical choices of Mood reflect the ideological 
positions implicit in the speeches and the conviction of the speakers to their proposals.

\section{Theoretical framework}

\section{Critical Discourse Analysis}

Critical discourse analysis (CDA) is a research paradigm which linguistically addresses the prevailing social problems by opposing dominant ideological positions. It chooses the perspectives of those who suffer most and critically analyses those in power, those who are responsible and those who have the means and the opportunity to solve such problems and to improve conditions (Wodak and Meyer 10). CDA proponents share the view that the relationship between language and society is dialectical: that is; discourse is shaped by social structure and at the same time shapes the social structure. (Johnstone 9-18). CDA scholars therefore believe that since discourse is used to construct unequal power relations, discourse through CDA can also be used to subvert and deconstruct them. These scholars employ linguistics in the development of a critique of linguistic practices which conceal how they are manipulative and to create awareness to the "subjected", even probably to the dominant group who may be unaware of them. Two concepts feature prominently in all CDA research. These include the concepts of "power" and "ideology". These two concepts are discussed in the following sections to highlight their implications to CDA.

\section{Power}

The whole research efforts in CDA are centred on the discursive dimensions of use and abuse of power. As has been mentioned earlier, discourse within social institutions is said to be structured by dominance. Moor and Henry (127) (qtd in 
Wareing (11) describes power as: "The force in society that gets things done and by studying it, we can identify who controls what, and for what benefit". CDA sees power as a central condition in social life. Even when two people are engaged in casual conversation, each participant is concerned with how to make his/her viewpoint dominate the other. Discourse and texts are therefore seen as interpersonal sites of struggle for dominance.

\section{Ideology}

Ideology, on the other hand, has been defined as a complex body of ideas, beliefs, values and insights we hold as individuals and groups that influence and direct our behaviour and serve as a basis for our actions as individuals and as groups (Ogunmodede $\mathrm{x}$ ). This definition sees ideology as simply a worldview and not as a negative concept. Another definition sees ideology in its pejorative sense as "a system of ideas and beliefs about human conduct which has normally been simplified and manipulated in order to obtain popular support for certain actions and which is usually emotive in its reference to social action" (Watson and Hill 129)

This last definition of ideology tended towards Marxist orientation which has influenced most CDA thought. The term, in fact, was credited to Karl Marx; the German political philosopher (1818-1883), who believed that ideologies were false systems of political, social and moral concepts invented and preserved by the ruling class out of self-interest (Ogunmodede vii). CDA proponents believe that every language use is ideologically motivated, that language may be deployed in the service of the dominant group to the detriment and repression of the less-privileged, that all linguistic usages encode different ideologies resulting from their different situations and purposes and by these means, language works as a form of social practice (Fairclough Linguistic Encyclopedia 
102). The end product of CDA is to create awareness and raise the consciousness of text producers and consumers to refrain from texts that are repressive and embrace ones that create harmony and protect the welfare of all institutional subjects. In the following section, we discuss in detail the functionalist framework on which our argument is based.

\section{The Systemic Functional Framework}

Scholars who have worked in the area of CDA recognize the relevance of Halliday's theoretical framework, the systemic functional grammar, as the most appropriate analytical model, a useful descriptive and interpretative framework for studying language as a social semiotic and as a text or discourse. The model explores the grammar of the metafunctions of language - that is, the meaning potentials carried by language. As stated earlier in our introductory section, Halliday sees language as conveying three meaning components simultaneously in a piece of text namely, the ideational, the interpersonal and the textual functions. The notions of transitivity, mood/modality and theme realize respectively these meaning potentials at the lexicogrammatical level and these are also related respectively to the contextual dimensions of field, tenor and mode. (Eggins 141-187, 207-253 and 296-326; see also Halliday's Social Semiotic 21, 39). Interpersonal meaning is expressed in the lexicogrammar by the features of Mood and Modality. Since our focus in this paper is the grammar of interpersonal meaning in the selected inaugural speeches, we shall concentrate on the Mood system.

\section{The Mood System}

Mood in SFG has been described as "the grammar of the clause in its interpersonal aspect" or "the grammar of personal 
participation" (Halliday Explorations 42), what gives the clause its potential as a means for the exchange of information and goods and services, a means by which interactants enact their roles and relationships. In the Mood structure, the clause is organized as an interactive event involving speaker/writer, audience/reader/addressee and other interactants in the discursive event who are constantly referred to for background information. In this capacity, the clause takes on the potential of "an exchange" - "exchange of information" (a "proposition") and exchange of "goods and services" (a "proposal") (Halliday and Matthiessen 110).

Thus, the grammatical system of Mood realizes the semantic system of what Halliday and Matthiessen (593) referred to as SPEECH FUNCTIONS. Speech functions involve 'propositions' and 'proposals'; giving and demanding information/goods and services through the use of statements, questions, offers and commands (Eggins 146). When language is used to exchange information the clause takes on the form of a proposition that is, something that can be argued about, affirmed or denied, something that can be judged in terms of validity or truth value (true/false). Propositions are realized by the indicative Mood (declarative and interrogative Mood), that is, by statements and questions concerning information about how the world is or ought to be ("it is"/"it isn't") (Halliday and Matthiessen 633). When language is used to exchange goods and services, the clause takes the form of a proposal. A proposal cannot be argued, affirmed or denied, rather, the addressee may decide to accept or reject the goods and services offered (Halliday and Matthiessen 111). A proposal is directed at the addressee in the form of offers and commands using the imperative Mood (do it or don't do it), or its tempered variant in the form of declarative (I urge you to do it/not to...). In the speeches that are the subject of this paper, we find that most of the clauses chosen are propositional in 
nature while those that convey proposals used the tempered variants of the imperative.

The Mood element consists of the Subject (a nominal element) and the Finite (a verbal element) and carries the nub of the argument, the burden of the clause which cannot disappear from the clause when the responding speaker takes up his/her position (113-117). The Subject is regarded as the "anchor" of the proposition or proposal. It supplies what it takes for the proposition or the proposal to be affirmed or denied or to be desirable or undesirable respectively. The success or failure of the proposition or proposal is vested on the Subject. It is the element of the clause that carries the "modal responsibility". The Subject is also the unmarked Theme in a declarative clause ((Halliday and Matthiessen 163). Modal responsibility implies that the validity or otherwise of the interactive event is vested on the Subject. We shall see in our sample texts how the choice of the Subject by the speakers assign them with, or divest them of modal responsibility to the various propositions and proposals encoded in the selected clauses.

Vocatives are also an aspect of the Mood structure that are strategically used to satisfy "face wants" of interactants in the speeches. Whereas positive face in politeness principle helps interactants to establish solidarity and intimacy, negative face is face threatening and emphasizes hierarchy and dominance. On the basis of the foregoing theoretical framework, we analyze our textual data to determine the following:

- How the speakers' choice of Subject position them as "modally responsible" to their proposals.

- How the choice of speech functions and vocatives show the speakers commitment to their speeches. 
- What power relations are at play in the speeches by these analyses?

The speeches are referred to as Speech1 and Speech 2 in our analysis. Speech 1 is Obasanjo's speech (1999) while Speech 2 is Shagari's speech (1979).

\section{Data Analysis}

Table 1: Summary of the Mood Structure of the Speeches

\begin{tabular}{|c|c|c|c|c|}
\hline & \multirow[t]{2}{*}{ Mood } & \multirow[t]{2}{*}{ Function } & \multicolumn{2}{|c|}{$\begin{array}{l}\text { Occurrence in } \\
\text { the Speeches }\end{array}$} \\
\hline & & & $\begin{array}{l}\text { Speec } \\
\text { h } 1\end{array}$ & $\begin{array}{l}\text { Speec } \\
\text { h } 2\end{array}$ \\
\hline $\mathrm{A}$ & Subject & $\begin{array}{l}\text { "Speaker" (I, my } \\
\text { government/administration } \\
\text { "Speaker+" (we, our } \\
\text { government/administration } \\
\text { ) } \\
\text { "addressee" (you) } \\
\text { Non interactant subjects } \\
\text { (others) }\end{array}$ & $\begin{array}{l}23 \\
16 \\
3 \\
136 \\
\mathbf{1 7 8}\end{array}$ & $\begin{array}{l}18 \\
33 \\
4 \\
106 \\
\mathbf{1 6 1} \\
\end{array}$ \\
\hline B & $\begin{array}{l}\text { Mood } \\
\text { Types }\end{array}$ & $\begin{array}{l}\text { Declarative } \\
\text { Imperative } \\
\text { Bound }\end{array}$ & $\begin{array}{l}148 \\
4 \\
26 \\
178\end{array}$ & $\begin{array}{l}123 \\
9 \\
29 \\
161\end{array}$ \\
\hline $\mathrm{C}$ & $\begin{array}{l}\text { Speech } \\
\text { Functions } \\
\text { Total }\end{array}$ & $\begin{array}{l}\text { Propositions } \\
\text { Proposals }\end{array}$ & $\begin{array}{l}130 \\
48 \\
\mathbf{1 7 8}\end{array}$ & $\begin{array}{l}112 \\
49 \\
\mathbf{1 6 1}\end{array}$ \\
\hline $\mathrm{D}$ & $\begin{array}{l}\text { Vocative } \\
\mathrm{S}\end{array}$ & Face Wants & 3 & 3 \\
\hline
\end{tabular}


Samples of texts to illustrate some of the textual features in Table 1 are given below.

\section{Text 1: Speaker as Subject Speech I}

I shall ... reintroduce civil service rules and (I) enforce compliance

I have worked out measures

I will give the forthright purposeful, committed honest and transparent leadership that the situation demands.

I am determined to build a broad consensus among all parties to enhance national harmony and stability

I will endeavour to heal divisions...

I intend to reconcile all those who feel alienated

I am determined to stretch my hand of fellowship to all Nigerians regardless of their political affiliations

\section{Speech 2}

I will continue to advance and defend the cause of our great country before the world community of nations.

I will take necessary action to effect remedies in the interest of the nation

The above samples illustrate the Speaker (I) in Subject positions as directly-involved participant in the unfolding actions. The Finite elements are more of temporal operators which construe propositions (giving information of actions) than high modal operators that construe proposals (offering 
goods and services). The propositions seem to be tentative and indeterminate

\section{Text 2: Speaker + other as Subject (Plural "We") Speech 1}

Let us rise as one to face the task ahead and (we) turn this daunting scene into opportunities in a New Dawn.

Let us make this the beginning of a genuine Renaissance

We must change our ways of governance and of doing business

...we shall take steps to halt the decline in the human development indices...

\section{Speech 2} housing

We will vigorously attack the problem of

We will immediately create new layout to be serviced by adequate drainage system.

Our party made strong commitment to the people of this country to rapidly develop and improve agriculture..

We shall map out strategies to encourage

Nigerian to engage in fruitful agricultural activities.

We are dedicated to building a viable economy by fostering broad mass participation...

We are determined to transform Nigerian Agriculture...

We also plan to make education more qualitative ... etc.

The use of "we"/ "our" as Subject is replete in the speeches especially in Speech 2. This inclusive "we" used 
interchangeably with the first person singular makes the speaker to hide in the crowd of "other" participants. The speaker is thus not directly responsible for the specified actions as the "we" does not refer explicitly to the speaker rather to other unknown Subjects which include the speaker. The clauses with "we" as Subject convey more of proposals and show more commitment by the use of more finite temporal operators than modal operators.

\section{Text 3: Non interactant Subjects as Grammatical Subject Speech 1}

Corruption, the greatest single bane of society today will be tackled head on...

The rampant corruption in the public service will be stamped out...

A determined effort will be made to cut down significantly the incidence of violent crime.

The public officer must be encouraged to believe ...that integrity pays.

His self respect must be restored.

His work must be fairly rewarded.

\section{Speech 2}

Continuous research will be under taken ...

...factories will be established

Issues will be reviewed

The Federal Government will give equal treatment to each state...

The use of non-interactant Subject allows the speaker to shirk modal responsibility, so that there would be no commitment or responsibility to the proposals. This type of structure is realized by what is known as "agentless passives" in traditional grammar. 


\section{Text 4: Speaker+ Other/Addressee as Subject}

Speech 1: You the good people of Nigeria elected me, a man who had walked through the valley of the shadow of death, as your President, to head a democratic civilian administration.

We give praise and honour to God for this day specially appointed by God Himself...

Speech 2: We are assuming office as a result of a free, democratic and peaceful election.

We must be proud of this.

In Text 4, the speakers want the readers to acknowledge the validity of the propositions, and to identify with them on the authenticity of the assertions in the propositions by the use of inclusive "we" and the assertive "you". The truth value of these propositions was taken for granted as 'given'. The speakers did not give room for the addressee and other included interactants to accept or deny the proposition.

\section{Text 5: Choice of Vocatives \\ Speech 1}

Fellow Nigerians, we give praise and honour to God for this day specially appointed by God Himself...

Fellow Nigerians let us rise as one to face the tasks ahead... Fellow Nigerians, the entire Nigerian scene is very bleak indeed...

\section{Speech 2}

Fellow Nigerians, we have witnessed today the birth of the Second Republic of Nigeria... 
Fellow citizens, great challenges and opportunities are before us...

Fellow citizens, know that the elections are over...

\section{Discussion}

The Mood system specifies the interpersonal structure of the clause as an exchange of information/goods and services. From our analysis, there is a high prevalence of finite temporal operators (be, have, do) which give the speeches their propositional structure - that of exchange of information hence a high prevalence of propositions as against proposalsexchange of goods and services- expressed by modal operators (must, will). This conclusion was further illustrated by the high prevalence of declarative clauses.

The use of personal pronouns (I, we, you), and possessive (my government/administration, our government/administration) in potential Subject positions is seen as ideologically motivated. As we already noted in our review of literature, the Subject in the Mood structure specifies the responsible element in the proposition or proposal. It is that element on which the validity of the information is made to rest (Halliday and Mathiessen 117). The choice of Subject by a speaker is guided by two considerations. Firstly, a speaker chooses as Subject that linguistic element which they would want to assign modal responsibility and secondly, that item which they want to make prominent as Theme, and which they are calling on the listener to acknowledge and verify. Thus the unmarked Theme of a declarative clause is its Subject.

Data from Table 1 shows that only a few of the sampled clauses positioned the speakers in Subject positions as the modally-responsible agent in the role relationships of the speeches. There was a deliberate oscillation in the use of "I" 
and "we", "my" and "our" in potential Subject positions. This shift could be interpreted as deliberate manipulation by the speakers aimed at either claiming or disclaiming responsibility depending on the issue at stake. It seems that "we" is used when the speaker is in doubt of the verifiability or acceptability of the proposition or proposal. If the proposition/proposal fails, the speaker would not be held modally responsible for the claim. On the other hand, "I" is used when the speaker is on safer grounds and wants to claim responsibility for positive achievement. This is to support the assertion by Jones and Wareing (46) on the implication of the shift in the use of personal pronouns - either to take credit for positive achievement or to disguise responsibility.

Yet another explanation to the shift in the use of singular and plural personal pronouns in Subject position could be that "we" is used when the speakers want to adopt a "facepreserving act" (Yule Pragmatics 61), when they need the solidarity of their audience, to identify with them as "in-group" and thus win their consent and perpetuate their hegemonies. In that case, the asymmetry in power is attenuated by the use of the inclusive "we". However when the speakers want to assert authority as one in control, they change to face-threatening acts by the use of singular "I" meaning "I am in charge here"

Bloor and Bloor (Functional 228) also claim that the grammatical use of possessive pronouns (my/our) in conjunction with nominals representing things that in fact cannot be owned in any real sense of the word is ideological. For instance, such expressions as "my government/administration" "our government/administration", "our country", "our people" - which are replete in the two speeches - can colour people's attitudes to the world, and in addition to encouraging traditional loyalty, care and other natural emotions, can also distort the ugly side of issues making them more acceptable and thus divert the audience 
attention from any hidden agenda. The speeches made such appeals to the emotion of Nigerians that little attention was paid at the time to whether the "addressee" actually share the "ownership" of these domains with the speakers and how most, if not all of the lofty proposals could be actualized.

The use of "you" and some instances of "we" in Subject positions in the speeches tend to invest the burden of modal responsibility on the addressee (Nigerians) and the Speakers plus other participants (Nigerians) even when the speech-functional import of such propositions are questionable. They leave the addressee with no option for acknowledgement or denial of the proposition. Samples of such clauses are presented in Text 4. Few Nigerians would wholly subscribe to this representation of the two electoral processes referred to by the speakers but because these represent the written "truth" of the dominant ideology and the political elite vested with overwhelming political power, no consideration was given to the unwritten, muted skepticism of Nigeria's teeming millions as to the veracity of the stated assertions.

Table 1 equally shows a high prevalence of noninteractant Subjects with finite temporal operators in declarative clauses making the speeches more of an exchange of information (propositions) than of offering goods and services (proposals). These non-interactant Subjects remove modal responsibility away from the speaker's persona.

Finally we considered the use of Vocatives in the speeches as a means of achieving interpersonal rapport. The Vocative "Fellow Nigerians" and its variants "Fellow Citizens"/"My fellow citizens" was given prominence as an interpersonal Theme - as the first linguistic choice at the beginning of the two speeches and at other strategic points in the body of the speeches. They serve the speakers' purposes of 
winning positive face of solidarity and attention of the audience and also ostensibly signal a positive mark of attitude (Quirk and Greenbaum 182-183). The speakers were calling on Nigerians to identify with them on the basis of equality and this is taken for-granted. In reality, there existed and still exists a very wide social distance between the power elite and the led in Nigeria and Nigerians are becoming increasingly suspicious of the Vocative "Fellow Nigerians" as the users of this infamous jargon have inflicted more suffering than fellowship on them.

\section{Conclusion}

The work has made a case, through the application of the systemic functional model and the critical discourse analysis, that the way language is structured, what is given prominence, what is assigned modal responsibility, the various lexicogrammatical choices employed in a text have a lot of information to offer on the ideologies that are projected by such language use. Interpersonal meaning and in fact all meaning potentials are said to reside in the systemic patterns of choice and our lexical and grammatical choices are predetermined by our various ideologies.

Our textual data have revealed how choices in the lexicogrammar can become veritable instruments of the power elite in manipulation, propaganda, deceit and denial of the basic sustenance of the less dominant, to the point that they accept the status quo as legitimate. We argue in this work that language use among the power elite need not be a shroud of mystery, deceit, propaganda and the so-called diplomacy which ultimately create an atmosphere of distrust, sycophancy and rancor, rather it should be geared towards transparency, equity and justice which have been the battle cry of successive governments in Nigeria but has hitherto been too illusive. 


\section{Funding Acknowledgement}

The manuscript for this publication was prepared with the support of an African Humanities Program (AHP) Fellowship, established by the American Council of Learned Societies (ACLS) and supported financially by the Carnegie Corporation of New York.

Chinwe R. Ezeifeka is of the Department of English Language \& Literature, Nnamdi Azikiwe University, Awka.

\section{Works Cited}

Bloor, Thomas and Meriel Bloor. The Functional Analysis of English: A Hallidayan Approach. $2^{\text {nd }}$ ed. London: Hodder Education, 2004.

Dawodu.com. "Shagari's Inaugural Address to Nigerians" October, 1, 1979.

http://www.dawodu.com/shag/htm. accessed 11/05/09..

Eggins, Suzanne. An Introduction to Systemic Functional Linguistics. $2^{\text {nd }}$ ed. New York: Continuum, 2004.

Fairclough, Norman. Critical Discourse Analysis: The Critical Study of Language. Essex: Longman: Group Ltd, 1995.

--- "Critical Linguistics/Critical Discourse Analysis". The Linguistic Encyclopedia. $\quad 2^{\text {nd }}$ ed. Ed. Kirsten Malmkjaer. London: Routledge, (2002), 102-106.

Halliday, Michael A.K. Explorations in the Functions of Language. London: Edward Arnold (Publishers) Ltd, 1973.

---. Language as Social Semiotic. The Social Interpretation of Language and Meaning. London: Edward Arnold, 1978. 
Halliday, Michael A. K. and Christian M. M. Matthiessen. An Introduction to Functional Grammar. $3^{\text {rd }}$ ed. London: Hodder Arnold, 2004.

Jones, Jason and Shan Wareing. "Language and Politics". Language, Society and Power, An Introduction. Eds. Linda Thomas and Shan Wareing. London: Routledge, (2000), 31- 47.

McGregor, Sue L. T. Critical Discourse Analysis: A Primer. Online: $\quad$ http://www.kon.org/archives/forum/151/mcgregorcda.html, accessed 18/02/08.

Nigeria World Publication. "Inaugural Speech by His Excellency, President Olusegun Obasanjo

following his Swearing-in as President of the Federal Republic of Nigeria on May 29, 1999" http://nigeriaworld.com/feature/speech inaugural. Accessed 11/05/09.

Ogunmodede, Francis I. Marxist Ideological Influence in Africa: The End of an Era? Benin-City: Ava Publishers, 2005.

Quirk, Randolph. And Sidney Greenbaum. A University Grammar of English. Edinburgh: Pearson Education Ltd, 2000.

Wareing, Shan. "What is Language and What does it do?" Language, Society and Power. Eds. Linda Thomas and Shan Wareing. London: Routledge, (2000), 1-15.

Watson, James and Ann Hill. Dictionary of Media and Communication Studies. $7^{\text {th }}$ ed. London: Hodder Arnold, 2006.

Wodak, Ruth. "Aspects of Critical Discourse Analysis". http://www.uni-

koblenz.deldiekmann/zfalarchiv/zfal36/.pdf. Accessed 30/7/08. 5-31. 
--- $\quad$ "Critical Discourse Analysis' Online
$<$ http//www.qualitativereserach.net/fgs-texts-
2-07/07-2-29e.htm? accessed 19/2/08.

--- "The Discourse-Historical Approach". Methods of Critical Discourse Analysis. Eds. Ruth Wodak and Michael Meyer. London: Sage, (2005), 63-94.

Wodak, Ruth and Michael Meyer. Methods of Critical Discourse Analysis. London: Sage, 2005.

Yule, George. Pragmatics. Oxford. 